\title{
Sistem Peramalan Kebutuhan Stok Obat Menggunakan Metode Holt-Winters
}

\author{
Eliza Staviana $^{1)}$, Kusrini $^{2}$, Emha Taufiq Luthfi ${ }^{3)}$ \\ Magister Teknik Informatika Universitas Amikom Yogyakarta \\ Jl. Ringroad Utara, Contong Catur, Sleman, Yogyakarta 55283 Indonesia \\ 12elizhastaviana@gmail.com, ${ }^{2}$ kusrini@amikom.ac.id,3emhataufiqluthfi@amikom.ac.id
}

\begin{abstract}
Abstrak
Pembelian stok obat di RS Budi Sehat Purworejo masih memiliki kendala misalnya terjadi penumpukan atau kekurangan stok obat. Hal tersebut dikarenakan RS Budi Sehat masih melakukan pembelian stok obat secara konstan setiap periodenya. Hal ini mengakibatkan terjadinya penumpukan stok obat apabila terjadi penurunan penjualan obat. Tujuan penelitian ini adalah meramalkan kebutuhan stok obat menggunakan metode Holt-Winters berdasarkan data obat sebelumnya. Penelitian ini menggunakan metode Holt-Winter dengan sampling sebanyak 784 item dan menggunakan Mean Absolute Percentege Error (MAPE) untuk perhitungan error. Hasil peramalan menggunakan metode Holt-Winters error (tingkat kesalahan) yang diukur dengan MAPE adalah $89 \%$. Hal ini menunjukan metode HoltWinters sangat bagus dalam meramalkan stok obat masa datang. Hasil akhir dari penelitian ini diharapkan dapat membantu proses perhitungan peramalan obat masa mendatang secara mudah, memperkecil kesalahan, dan menghasilkan ramalan yang akurat dan cepat.
\end{abstract}

Kata Kunci:Peramalan, Metode Holt-Winter, Metode MAPE

\section{PENDAHULUAN}

a. Latar Belakang

RS Budi Sehat merupakan salah satu rumah sakit swasta yang berlokasi di Kota Purworejo. RS Budi Sehat telah beroperasi sebagai sebuah rumah sakit \pm 4 tahun, di mana sebelumnya merupakan klinik umum dan bersalin. Meskipun secara umur, RS Budi Sehat masih tergolong baru dalam bisnis rumah sakit, namun RS Budi Sehat memiliki komitmen yang tinggi dalam memberikan pelayanan kesehatan bagi masyarakat Purworejo dan sekitarnya. Komitmen ini dibuktikan dengan predikat akreditasi yang diperoleh, yaitu rumah sakit tipe D dengan status akreditasi bintang 3 atau tingkat madya. Pada gambar 1 ditampilkan status akreditsi untuk RS Budi Sehat Purworejo (sumber: http://akreditasi.kars.or.id/accreditation/report /report accredited.php).

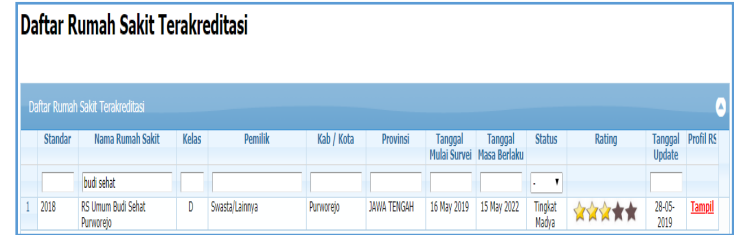

Gambar 1. Status akreditas RS Budi Sehat Purworejo

Pada 27-30 Mei 2019 dilaksanakan proses akreditasi di RS Budi Sehat oleh Komite Akreditas Rumah Sakit (KARS). KARS merupakan komite khusus yang memberikan penilaian terhadap kualitas pelayanan sebuah rumah sakit. Peringkat atau status akreditas mengindikasikan kualitas pelayanan yang diberikan oleh sebuah rumah sakit. Dengan umur yang terbilang muda, RS Budi Sehat telah memperoleh status rumah sakit tingkat madya, artinya bahwa RS Budi Sehat dianggap sebagai rumah sakit yang memiliki komitmen tinggi dalam menjaga kualitas pelayanan.

Pada proses akreditasi ini, digunakan instrument SNARS (Standar Nasional Akreditas Rumah Sakit), yang mana terdapat 16 standar yang akan dinilai. Untuk meraih status tingkat madya, maka nilai total seluruh standar minimal adalah 80. Meskipun telah 
memperoleh status tingkat madya, namun tidak seluruh standar dapat melampaui nilai 80. Salah satu standar atau instrument yang mendapatkan nilai kurang memuaskan adalah Pelayanan Kefarmasian dan Penggunaan Obat (PKPO). Pada standar PKPO 2.1 terkait dengan regulasi pengadaan sediaan farmasi, tim surveyor KARS memberikan rekomendasi agar RS Budi Sehat menerapkan sebuah mekanisme yang dapat digunakan untuk memprediksi kebutuhan obat mengikuti tren musiman.

Meskipun pada saat ini RS Budi Sehat telah memanfaatkan sistem informasi berbasis komputer untuk menunjang kegiatan operasionalnya, namun masih terbatas pada kegiatan operasional harian setiap unit. Khusus untuk instalasi farmasi, belum terdapat mekanisme untuk memprediksi kebutuhan stok seperti yang direkomendasikan oleh tim surveyor KARS.

Menilik hal tersebut di atas, maka dalam penelitian ini penulis mengangkat topik "Sistem Peramalan Kebutuhan Stok Obat dengan Menggunakan Metode Holt-Winters" dengan studi kasus di RS Budi Sehat Purworejo. Pemilihan metode Holt-Winters adalah dengan pertimbangan bahwa metode Holt-Winters sangat baik untuk digunakan dalam meramalkan berdasarkan data baik yang bersifat musiman maupun tidak. Selain itu, diharapkan agar nantinya hasil penelitian ini dapat diimplementasikan di RS Budi Sehat Purworejo.

\section{METODE PENELITIAN}

\section{a. Jenis, Sifat dan Pendekatan Penelitian}

Penelitian ini dilakukan dengan metode kualitatif deskriptif. Penelitian kualitatif adalah jenis penelitian yang menghasilkan penemuan penemuan yang tidak dapat dicapai dengan menggunakan prosedur prosedur statistik atau dengan cara kuantifikasi lainnya (Sudikin, 2002).

Penelitian deskriptif bermaksud memberikan gambaran suatu gejala sosial tertentu, sudah ada informasi mengenai gejala sosial seperti yang dimaksudkan dalam suatu permasalahan penelitian namun belum memadai. Penelitian deskriptif menjawab pertanyaan apa dengan penjelasan yang lebih terperinci mengenai gejala sosial seperti yang dimaksudkan dalam suatu permasalahan penelitian yang bersangkutan. Penelitian deskriptif dilakukan terhadap variable mandiri, yaitu tanpa membuat perbandingan atau menghubungkan dengan variable yang lain (Sugiyono, 2011). Obyek dari penelitian ini adalah Instalasi Farmasi RS Budi Sehat Purworejo. Sedangkan subyek dari penelitian ini adalah Staf Instalasi Farmasi RS Budi Sehat Purworejo. Dengan mempergunakan data penggunaan obat tahun 2015-2018 sebagai data pelatihan, maka akan dilakukan peramalan kebutuhan stok obat pada tahun 2019. Hasil peramalan ini akan dibandingkan dengan data actual tahun 2019 dan akan dihitung tingkat akurasinya menggunakan metode MAPE.

\section{b. Metode Pengumpulan Data}

Metode pengumpulan data yang digunakan dalam penelitian ini adalah:

1) Studi Pustaka

Metode ini dilakukan dengan studi literatur terkait mengenai konsep evaluasi kinerja dosen melalui buku maupun hasil penelitian-penelitian terdahulu mengenai peramalan.

2) Wawancara

Metode ini dilakukan melalui tanya jawab dengan Staf Instalasi Farmasi RS Budi Sehat Purworejo.

3) Pengambilan data langsung dari sistem yang berjalan saat ini. Yaitu data penggunaan obat untuk tahun 2015-2019.

\section{c. Metode Analisis Data}

Analisis data dilakukan dengan menggunakan data pemakaian obat tahun 2015-2018 sebagai data latih. Dengan data latih tersebut akan diketahui tren musiman pemakaian obat. Selanjutnya berdasarkan nilai tren yang diperoleh akan diramalkan kebutuhan stok obat tahun 2019. Setelah nilai ramalan diketahui, akan dibandingkan dengan data actual tahun 2019. Dan selanjutnya dengan menggunakan metode MAPE akan dihitung tingkat akurasi sistem dalam meramalkan kebutuhan stok obat.

\section{d. Alur Penelitian}

Alur yang dipergunakan dalam penelitian ini mengikuti tahapan penelitian tindakan (Action Research) menurut Baskerville (1999) sebagai berikut:

1) Melakukan diagnose (Diagosing)

Pada tahapan ini dilakukan proses identifikasi masalah-masalah yang menjadi dasar penelitian terkait dengan prediksi 
kebutuhan stok obat. Selain itu juga dilakukan proses pengumpulan data.

2) Membuat rencana tindakan (Action Panning)

Tahapan action planning merupakan tahapan perencanaan tindakan guna menentukan tindakan yang tepat dalam rangka penyelesaian masalah yang diangkat dalam penelitian ini. Tahapan ini meliputi pemodelan, untuk memodelkan peramalan kebutuhan stok obat.

3) Melakukan evaluasi (Evaluation)

Tahapan evaluasi merupakan tahapan pengujian. Pengujian dilakukan dengan membandingkan hasil peramalan sistem dengan data aktual. Dengan menggunakan metode MAPE akan diketahui tingkat akurasi sistem.

4) Melakukan review (Reflection)

Tahap ini merupakan bagian akhir dari tahapan penelitian, dan pada tahapan ini dilakukan review atas hasil penelitian yang sudah dilakukan.

Tahapan penelitian dapat dilihat pada gambar 2.

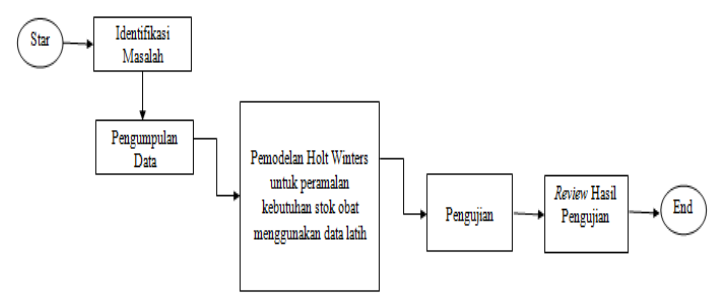

Gambar 2. Alur penelitian

\section{TINJAUAN PUSTAKA}

Pada bagian ini akan diuraikan beberapa penelitian yang telah dilakukan, di mana penelitian-penelitian tersebut memiliki topic yang sama dengan penelitian yang akan dilakukan ini

a. Affandi dkk (2018) melakukan penelitian berjudul "Peramalan Stok Obat di Puskesmas Gending Probolinggo Menggunakan Metode Winter's Exponential Smoothing". Dalam penelitian ini dikembangkan sistem peramalan stok obat berbasis web dengan menerapkan metode Winters Exponential Smoothing untuk mempermudah puskesmas tersebut dalam melakukan pembelian stok obat. Metode ini diterapkan untuk melakukan peramalan jumlah stok obat yang akan dibeli pada periode berikutnya. Parameter yang digunakan dalam metode ini menggunakan data penjualan obat bulanan tahun 2015 - 2016. Selanjutnya data tersebut diuji menggunakan metode ini sehingga menghasilan tingkat akurasi peramalan Mean Absolute Percentage Error (MAPE) yang tinggi, yaitu di atas $20 \%$.

b. Hendriani dkk (2016) melakukan penelitian dengan judul "Sistem Peramalan Persediaan Obat dengan Metode Weight Moving Average dan Reorder Point (Studi Kasus: Puskesmas Soropia)". Penelitian tersebut bertujuan untuk menghasilkan sistem peramalan sehingga dapat mengatasi permasalahan terkait dengan kelebihan ataupun kekurangan stok obat di Puskesmas Soropia. Metode peramalan yang digunakan adalah Weight Moving Average dan Reorder Point. Berdasarkan hasil pengujian akurasi peramalan oleh sistem menggunakan metode MAPE, dihasilkan tingkat tingkat akurasi sebesar $70 \%$.

c. Pradnyana dkk (2017) melakukan penelitian berjudul "Pengembangan Aplikasi Pengendalian Persediaan Obat di Apotek Menggunakan Metode Hybrid Periodic Order Quantity - Moving Average". Dalam penelitian-penelitian yang dilakukan sebelumnya didapat kelemahan bahwa metode Periodic Order Quantity kurang mampu dalam memprediksi jumlah barang harus dipesan secara tepat, sedangkan metode Moving Average dikatakan mampu meramalkan tren terbaru selama periode waktu tertentu dengan menghitung bobotnya. Oleh karena itu dalam penelitian tersebut Pradnyana dkk menggabungkan kedua metode tersebut untuk pengendalian stok obat.

d. Dyatmika \& Krisnadewara (2017) melakukan penelitian berjudul "Pengendalian Persediaan Obat Generik dengan Metode Analisis ABC, Metode Economic Order Quantity (EOQ) dan Reorder Point (ROP) di Apotek AXY tahun 2017". Penelitian ini bertujuan untuk menganalisis pengendalian persediaan obat generik di Apotek XYZ tahun 2017. Untuk perencanaan pengadaan obat generik, dalam penelitian ini dilakukan analisis nilai investasi untuk mengetahui obat generik mana saja yang termasuk kelompok A, B, dan C. Selanjutnya dilakukan perhitungan Economic Order 
Quantity (EOQ) untuk mengetahui jumlah pesanan ekonomis, serta perhitungan Reorder Point (ROP) untuk mengetahui titik pemesanan kembali obat generik periode tahun 2017. Hasil analisis menunjukkan anlisis $\mathrm{ABC}$ investasi terdapat obat yang masuk ke dalam kelompok A sebanyak 11 jenis obat atau $16,42 \%$ dari seluruh obat generik, menyerap 70,41\% investasi, kelompok B sebanyak 15 jenis obat atau $22,39 \%$ dari seluruh obat generik, menyerap 20,09\% investasi. Sementara kelompok C sebanyak 41 jenis obat atau $61,19 \%$ dari seluruh obat generik item obat hanya menyerap sebesar $9,49 \%$ investasi. Didapatkan juga hasil perhitungan EOQ dan ROP untuk periode tahun 2017. Adanya perhitungan ini bermanfaat untuk membantu apotek dalam pengadaan obat generik sehingga terjadi keseimbangan antara tingkat pelayanan dan biaya.

\section{HASIL DAN PEMBAHASAN \\ a. Pemodelan Holt-Winters}

Proses prediksi jumlah obat menggunakan metode Holt-Winters ini dapat dilakukan apabila terdapat sekumpulan data time series tertentu selama beberapa periode, konstanta-konstanta prediksi dan panjang musiman untuk menghasilkan suatu nilai prediksi untuk periode berikutnya. Dalam penelitian yang akan dilakukan ini, proses peramalan akan dilakukan menggunakan data rekapitulasi jumlah obat yang direkap per bulan. Dengan menggunakan data ini, maka jumlah obat untuk bulan-bulan pada periode selanjutnya dapat diprediksi. Proses peramalan menggunakan metode Holt Winters yang dilakukan dalam penelitian ini akan mengikuti flowchart seperti ditunjukkan pada gambar.

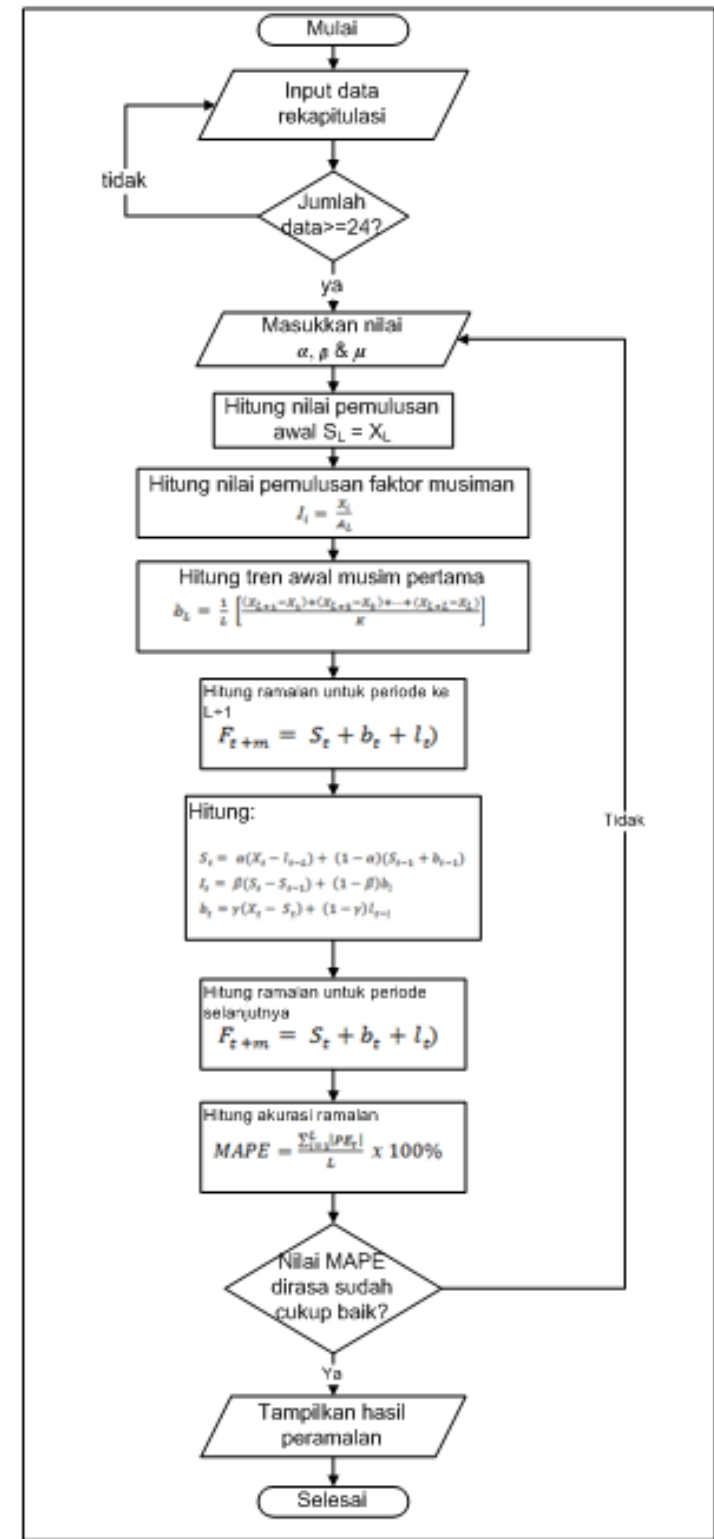

Gambar 3. Flowchart peramalan menggunakan metode Holt Winters

Untuk memperjelas prinsip peramalan menggunakan metode Holt Winters, pada bagian berikut ini akan diberikan contoh perhitungan peramalan jumlah obat. Misalnya diketahui bahwa rekapitulasi jumlah obat adalah seperti ditunjukkan oleh tabel.

Tabel 1. Contoh data rekapitulasi jumlah obat pada periode-periode lalu

\begin{tabular}{|c|c|}
\hline Bulan & Jumlah Obat \\
\hline Januari 2015 & 57 \\
\hline Februari 2015 & 62 \\
\hline Bulan & Jumlah Obat \\
\hline Maret 2015 & 60 \\
\hline April 2015 & 55 \\
\hline Mei 2015 & 65 \\
\hline Juni 2015 & 45 \\
\hline
\end{tabular}




\begin{tabular}{|c|c|}
\hline Juli 2015 & 46 \\
\hline Agustus 2015 & 50 \\
\hline September 2015 & 49 \\
\hline Oktober 2015 & 93 \\
\hline November 2015 & 82 \\
\hline Desember 2015 & 74 \\
\hline Januari 2016 & 60 \\
\hline Februari 2016 & 65 \\
\hline Maret 2016 & 73 \\
\hline April 2016 & 70 \\
\hline Mei 2016 & 76 \\
\hline Juni 2016 & 65 \\
\hline Juli 2016 & 53 \\
\hline Agustus 2016 & 59 \\
\hline September 2016 & 62 \\
\hline Oktober 2016 & 83 \\
\hline November 2016 & 78 \\
\hline Desember 2016 & 76 \\
\hline
\end{tabular}

Berdasarkan data pada tabel akan diramalkan jumlah obat untuk bulan januari 2017. Berikut adalah proses perhitungan yang dilakukan:

a. Dari data diketahui bahwa jumlah data adalah 2 musim dengan 24 periode bulan. Sehingga persyaratan memenuhi.

b. Tentukan nilai $\alpha, \beta$ dan $\mu$. Misalnya digunakan nilai $\alpha=0.2, \beta=0.3$ dan $\mu=$ 0.4 . Nilai ini bebas asalkan antara 0 dan 1 .

c. Hitung nilai $S_{L}$. Nilai $S_{L}$ awal dapat diinisialisasi menggunakan nilai $\mathrm{X}_{\mathrm{L}}$ yaitu rata-rata nilai aktual pada musim pertama, yaitu rekapitulasi jumlah obat pada tahun 2015. Sehingga didapat $S_{L}=61.5$.

d. Hitung nilai pemulusan faktor musiman $l_{\mathrm{i}}$. $1_{i}=\frac{X i}{A_{L}}$ dengan

$\mathrm{X}_{\mathrm{i}}=$ data aktual pada bulan ke-i

$A_{L}=$ rata-rata jumlah obat pada musim pertama.

Sehingga:

$\mathrm{A}_{\mathrm{L}}=\frac{57+62+60+55+65+45+46+50+49+93+82+74}{12}$ $=\frac{738}{12}=61.5$

$1_{1}=\frac{57}{61.5}=0.926829$

$1_{2}=\frac{62}{61.5}=1.00813$

$1_{3}=\frac{60}{61.5}=0.97561$

$1_{4}=\frac{55}{61.5}=0.894309$

$1_{5}=\frac{65}{61.5}=1.056911$

$1_{6}=\frac{45}{61.5}=0.731707$

$1_{7}=\frac{46}{61.5}=0.747967$ $1_{8}=\frac{267}{350.75}=1.054882$

$1_{9}=\frac{49}{61.5}=0.796748$

$1_{10}=\frac{93}{61.5}=1.512195$

$1_{11}=\frac{82}{61.5}=1.333333$

$1_{12}=\frac{82}{61.5}=1.203252$

e. Hitung tren awal musim pertama $b_{\mathrm{L}}$.

$$
\begin{aligned}
& \mathrm{b}_{\mathrm{L}}=\frac{1}{24}\left(\frac{75-57}{12}+\frac{74-62}{12}+\right. \\
& \frac{75-60}{12}+\frac{70-55}{12}+\frac{78-65}{12}+\frac{57-45}{12}+ \\
& \frac{51-50}{12}+\frac{62-49}{12}+\frac{111-93}{12}+\frac{67-82}{12}+ \\
& \left.\frac{80-74}{12}\right) \\
& \mathrm{b}_{\mathrm{L}}=0.399306
\end{aligned}
$$

f. Hitung ramalan untuk periode ke-13, $\mathrm{m}=13$

$$
\begin{aligned}
\mathrm{F}_{13} & =\left(\mathrm{S}_{\mathrm{L}}+\mathrm{b}_{\mathrm{L}}\right) \times \mathrm{l}_{\mathrm{L}} \\
& =61.5+0.926829+0.399306 \\
& =62.82613
\end{aligned}
$$

g. Setelah diperoleh nilai awal selanjutnya akan cari nilai penghalusan untuk data keseluruhan, trend dan musiman. $\mathrm{S}_{\mathrm{t}}=\alpha\left(X_{t}-l_{t-L}\right)+(1-\alpha)\left(S_{t-1}+\right.$ $\left.b_{t-1}\right)$

$\mathrm{S}_{13}=\quad 0.2(75-0.926829)+$

$(1-\alpha)\left(S_{L}+b_{L}\right)=14.81463+$

$(1-0.2)(61.5+$

$0.399306)=14.81463+49.5194448=$ 64.33408

$$
\begin{aligned}
& 1_{\mathrm{T}} \quad=\beta \frac{X_{t}}{S_{t}}+(1-\beta) I_{t-L} \\
& 1_{13} \quad=\quad 0.3 \quad \frac{75}{61.5}+ \\
& (1-0.3) 0.926829 \\
& =0.365853659+0.648780488 \\
& =1,014634146 \\
& \begin{array}{ll}
\mathrm{b}_{\mathrm{T}} & =\quad \gamma\left(S_{t}-S_{t-1}\right)+
\end{array} \\
& (1-\gamma) b_{t-1} \\
& \mathrm{~b}_{13}=\quad 0.4\left(S_{13}-S_{L}\right)+ \\
& (1-0.4) b_{L} \\
& =0.4(64.33408-61.5)+(0.6) \\
& 0.399306 \\
& 1.133631436314363 \\
& 0.2395836 \\
& 1.3732147696476962
\end{aligned}
$$

h. Hitung ramalan untuk periode ke-14, $\mathrm{m}=14$

$$
\begin{aligned}
\mathrm{F}_{14} & =\mathrm{S}_{13}+\mathrm{b}_{13}+\mathrm{l}_{2} \\
& =64.33408+1.3732147696476962 \\
& +1.203252033 \\
& =66.72192750677507
\end{aligned}
$$

Demikian seterusnya dilakukan sampai ke periode ke- 24 . 
i. Untuk menguji akurasi peramalan dapat dilakukan menggunakan rumus:

$$
\begin{aligned}
& M A P E=\frac{\sum_{i=1}^{L}\left|P E_{t}\right|}{L} \times 100 \% \\
& \text { Di mana } P E_{t}=\left|\frac{X_{t}-S_{t}}{X_{t}}\right|
\end{aligned}
$$

\section{b. Pengujian $M A P E$}

Tahapan selanjutnya adalah pengujian sistem. Dalam sistem peramalan yang dikembangkan, pengujian difokuskan untuk mengetahui akurasi hasil peramalan. Metode yang diumum digunakan untuk mengukur tingkat akurasi peramalan adalah MAPE (Mean Absolute Percentage Error). Dengan menggunakan metode MAPE maka dapat dihitung rata-rata prosentase error absolut. Untuk dapat mengukur akurasi, maka dibutuhkan data aktual dan data hasil ramalan, sehingga dapat dihitung nilai galat prosentase atau nilai $P E$.

Mengacu kepada data jumlah obat yang digunakan dalam penelitian ini, maka data pada tahum 2015 dapat dianggap sebagai data pada musim I, sedangkan data pada tahun 2016 merupakan data pada musim II. Data pada musim I akan digunakan sebagai dasar dalam melakukan peramalan untuk musim II, sehingga nantinya setelah diperoleh data ramalan pada musim II dan telah diketahui data aktual pada musim II, maka dapat dihitung nilai $P E$ untuk setiap periode. Pada tabel 1 disajikan hasil peramalan untuk musim II yang diperoleh dengan menggunakan sistem. Nilai ramalan tersebut didapatkan dengan menggunakan nilai alpa $=0.1$, beta 0.1 , dan tetta $=0.1$.

Tabel 1 Daftar hasil ramalan musim II pada percobaan I

\begin{tabular}{|l|c|}
\hline \multicolumn{1}{|c|}{ Periode } & Nilai Ramalan \\
\hline Januari 2016 & 57 \\
\hline Februari 2016 & 63 \\
\hline Maret 2016 & 63 \\
\hline April 2016 & 65 \\
\hline Mei 2016 & 66 \\
\hline Juni 2016 & 67 \\
\hline Juli 2016 & 67 \\
\hline Agustus 2016 & 66 \\
\hline September 2016 & 66 \\
\hline Oktober 2016 & 66 \\
\hline November 2016 & 68 \\
\hline Desember 2016 & 70 \\
\hline
\end{tabular}

Berdasarkan data pada tabel 1 selanjutnya akan dihitung nilai $P E$ untuk setiap periode seperti ditunjukkan oleh tabel 2.

\begin{tabular}{|c|c|c|c|}
\hline Periode & $\begin{array}{c}\text { Nilai } \\
\text { Ramalan } \\
\left(\mathrm{F}_{\mathrm{t}}\right)\end{array}$ & $\begin{array}{c}\text { Data } \\
\text { Aktual } \\
\left(\mathrm{X}_{\mathrm{t}}\right)\end{array}$ & $P E=\left|\frac{F_{t}-X_{t}}{X_{t}}\right|$ \\
\hline Jan 2016 & 57 & 60 & 0.05 \\
\hline Feb 2016 & 63 & 65 & 0.030769231 \\
\hline Mar 2016 & 63 & 73 & 0.136986301 \\
\hline Apr 2016 & 65 & 70 & 0.071428571 \\
\hline Mei 2016 & 66 & 76 & 0.131578947 \\
\hline Juni 2016 & 67 & 65 & 0.030769231 \\
\hline Juli 2016 & 67 & 53 & 0.264150943 \\
\hline Ags 2016 & 66 & 59 & 0.118644068 \\
\hline Sep 2016 & 66 & 62 & 0.064516129 \\
\hline Okt 2016 & 66 & 83 & 0.204819277 \\
\hline Nov 2016 & 68 & 78 & 0.128205128 \\
\hline Des 2016 & 70 & 76 & 0.078947368 \\
\hline & & & 1.310815196 \\
\hline
\end{tabular}

Tabel 2 Perhitungan nilai $P E$ percobaan I

Dari hasil pada tabel dididapatkan bahwa nilai total error untuk musim II adalah 1.29 (hasil pembulatan). Dengan menggunakan formula (2.8), maka nilai MAPE $=\frac{1.31}{12} \times 100 \%=10.92 \%$. Dari hasil ini, maka akurasi hasil peramalan pada pengujian pertama dengan nilai alpa $=0.1$, beta $=0.1$ dan tetta $=0.1$ diperoleh tingkat akurasi peramalan sebesar $89.18 \%$.

Selanjutnya jika nilai digunakan nilai alpa $=$ 0.5 , beta $=0.1$ dan tetta $=0.1$, maka diperoleh hasil peramalan seperti ditunjukkan oleh tabel 3. Berdasarkan hasil pada tabel 3, selanjutnya pada tabel 4 disajikan daftar perhitungan nilai $P E$ untuk percobaan II. Dari hasil pada tabel 4 didapatkan bahwa nilai total $P E$ pada percobaan II adalah 1.11, sehingga nilai $\mathrm{MAPE}=\frac{1.16}{12} \times 100 \%=9.25 \%$. Dengan nilai error sebesar $9.62 \%$, maka tingkat akurasi yang didapatkan pada percobaan II adalah sebesar $91.38 \%$.

Tabel 3. Daftar hasil ramalan musim II pada percobaan II

\begin{tabular}{|l|c|}
\hline \multicolumn{1}{|c|}{ Periode } & Nilai Ramalan \\
\hline Januari 2016 & 57 \\
\hline Februari 2016 & 62 \\
\hline Maret 2016 & 64 \\
\hline April 2016 & 69 \\
\hline Mei 2016 & 71 \\
\hline Juni 2016 & 74 \\
\hline Juli 2016 & 70 \\
\hline Agustus 2016 & 61 \\
\hline September 2016 & 60 \\
\hline
\end{tabular}




\begin{tabular}{|l|l|}
\hline Oktober 2016 & 61 \\
\hline November 2016 & 73 \\
\hline Desember 2016 & 76 \\
\hline
\end{tabular}

Tabel 4. Perhitungan nilai $P E$ percobaan II

\begin{tabular}{|l|c|c|r|}
\hline Periode & $\begin{array}{c}\text { Nilai } \\
\text { Ramalan } \\
\left(\mathrm{F}_{\mathrm{t}}\right)\end{array}$ & $\begin{array}{c}\text { Data } \\
\text { Aktual } \\
\left(\mathrm{X}_{\mathrm{t}}\right)\end{array}$ & $P E=\left|\frac{F_{t}-X_{t}}{X_{t}}\right|$ \\
\hline Jan2016 & 57 & 60 & 0.05 \\
\hline Feb2016 & 62 & 65 & 0.046153846 \\
\hline Mar2016 & 64 & 73 & 0.123287671 \\
\hline Apr2016 & 69 & 70 & 0.014285714 \\
\hline Mei2016 & 71 & 76 & 0.065789474 \\
\hline Juni2016 & 74 & 65 & 0.138461538 \\
\hline Juli2016 & 70 & 53 & 0.320754717 \\
\hline Ags2016 & 61 & 59 & 0.033898305 \\
\hline Sep2016 & 60 & 62 & 0.032258065 \\
\hline Okt2016 & 61 & 83 & 0.265060241 \\
\hline Nov2016 & 73 & 78 & 0.064102564 \\
\hline Des2016 & 76 & 76 & 0 \\
\hline & & & 1.154052135 \\
\hline
\end{tabular}

Pada percobaan III digunakan nilai alpa $=1$, beta $=0.1$ dan tetta 0.1. Pada tabel 5 disajikan hasil peramalan dengan menggunakan setingan parameter tersebut.

Tabel 5 Daftar hasil ramalan musim II pada percobaan III

\begin{tabular}{|l|c|}
\hline \multicolumn{1}{|c|}{ Periode } & Nilai Ramalan \\
\hline Januari 2016 & 57 \\
\hline Februari 2016 & 60 \\
\hline Maret 2016 & 65 \\
\hline April 2016 & 74 \\
\hline Mei 2016 & 71 \\
\hline Juni 2016 & 77 \\
\hline Juli 2016 & 65 \\
\hline Agustus 2016 & 52 \\
\hline September 2016 & 59 \\
\hline Oktober 2016 & 63 \\
\hline November 2016 & 85 \\
\hline Desember 2016 & 79 \\
\hline
\end{tabular}

Dengan menggunakan hasil pada tabel 5, selanjutnya dihitung nilai $P E$ untuk percobaan III sebagaimana ditunjukkan oleh tabel 6.

Tabel 6 Perhitungan nilai $P E$ percobaan III

\begin{tabular}{|c|c|c|r|}
\hline Periode & $\begin{array}{c}\text { Nilai } \\
\text { Ramalan }\left(\mathrm{F}_{\mathrm{t}}\right)\end{array}$ & $\begin{array}{c}\text { Data } \\
\text { Aktu } \\
\text { al } \\
\left(\mathrm{X}_{\mathrm{t}}\right)\end{array}$ & $P E=\left|\frac{F_{t}-X_{t}}{X_{t}}\right|$ \\
\hline Jan 2016 & 57 & 60 & 0.05 \\
\hline Feb 2016 & 60 & 65 & 0.076923077 \\
\hline Mar 2016 & 65 & 73 & 0.109589041 \\
\hline Periode & Nilai & $\begin{array}{c}\text { Data } \\
\text { Aktu } \\
\text { al } \\
\left(\mathrm{X}_{\mathrm{t}}\right)\end{array}$ & $P E=\left|\frac{F_{t}-X_{t}}{X_{t}}\right|$ \\
\hline Apr 2016 & 74 & 70 & 0.057142857 \\
\hline Mei 2016 & 71 & 76 & 0.065789474 \\
\hline
\end{tabular}

\begin{tabular}{|l|l|l|r|}
\hline Juni 2016 & 77 & 65 & 0.184615385 \\
\hline Juli 2016 & 65 & 53 & 0.226415094 \\
\hline Ags 2016 & 52 & 59 & 0.118644068 \\
\hline Sep 2016 & 59 & 62 & 0.048387097 \\
\hline Okt 2016 & 63 & 83 & 0.240963855 \\
\hline Nov2016 & 85 & 78 & 0.08974359 \\
\hline Des2016 & 79 & 76 & 0.039473684 \\
\hline \multicolumn{4}{|l}{} \\
\hline
\end{tabular}

Dari hasil percobaan III pada tabel 6 , diperoleh bahwa nilai total $P E$ adalah 1.26 (dibulatkan), sehingga nilai MAPE = $=\frac{1.31}{12} \times 100 \%=10.9 \%$. Dari hasil ini dapat dikatakan bahwa tingkat akurasi yang diperoleh pada percobaan III adalah $89.1 \%$.

Rangkuman hasil percobaan I, II dan III dapat dilihat pada tabel 7. Berdasarkan tabel 7, maka hasil pengujian dengan akurasi terbaik adalah $91.75 \%$. dengan nilai alpa $=$ 0.5 , beta $=0.1$ dan tetta $=0.1$.

Tabel 7 Rangkuman hasil percobaan

\begin{tabular}{|c|c|c|c|c|}
\hline Percobaan & Alpa & Beta & Tetta & Akurasi \\
\hline I & 0.1 & 0.1 & 0.1 & $89.18 \%$ \\
\hline II & 0.5 & 0.1 & 0.1 & $91.38 \%$ \\
\hline III & 1 & 0.1 & 0.1 & $89.1 \%$ \\
\hline
\end{tabular}

Hasil pengujian akurasi tersebut jika dimasukkan ke dalam klasifikasi kinerja peramalan seperti ditunjukkan oleh tabel 8 akan termasuk ke dalam kategori sangat bagus/ sangat baik, yaitu untuk nilai alpa $=$ 0.5 , beta $=0.1$ dan tetta $=0.1$.

Tabel 8 Klasifikasi kinerja peramalan (Zainun dan Majid, 2003)

\begin{tabular}{|c|c|}
\hline $\begin{array}{c}\text { Prosentase } \\
\text { error }\end{array}$ & Predikat Kinerja Peramalan \\
\hline$<10 \%$ & Sangat bagus/ baik \\
\hline $\begin{array}{c}>=10 \% \\
\text { dan } \\
<=20 \%\end{array}$ & Bagus/ Baik \\
\hline$>20 \%$ & Buruk/ Jelek \\
\hline
\end{tabular}

Nilai akurasi dapat dihitung dengan menggunakan ramalan pada peridoe ke-13 sampai dengan periode ke-24. Nilai $\alpha$, $\beta$ dan $\mu$ sangat berpengaruh terhadap akurasi nilai ramalan. Untuk itu dapat dicoba-coba kombinasi nilai $\alpha, \beta$ dan $\mu$ sehingga didapatkan tingkat akurasi yang terbaik. 


\section{KESIMPULAN DAN SARAN \\ a. Kesimpulan}

Hasil peramalan menggunakan metode Holt-Winters error (tingkat kesalahan) yang diukur dengan MAPE adalah $89 \%$. Hal ini menunjukan metode HoltWinters sangat bagus dalam meramalkan stok obat masa datang. Hasil akhir dari penelitian ini diharapkan dapat membantu proses perhitungan peramalan obat masa mendatang secara mudah, memperkecil kesalahan, dan menghasilkan ramalan yang akurat dan cepat.

\section{b. Saran}

Saran untuk lanjutan penelitian berikutnya bisa ditambahkan data kriteria dan jumlah data semakin banyak data yang diproses metode Holt-Winters maka akan mempengaruhi hasil nilai preferensi.

\section{REFERENSI}

Afaandi, L., Pradibta, H., \& Habibui, M.I., Peramalan Stok Obat di Puskesmas Gending Probolinggo Menggunakan Metode Winter's Exponential Smoothing, Jurnal Informatika Polinema, e-ISSN : 2407-070X p-ISSN: 2614-6371, Volume 4, Edisi 4 Agustus, 2018.

Dyatmika, S.B \& Krisnadewara, P.D., Pengendalian Persedian Obat Generik dngan Metode Analisis ABC, Metode Economic Order Quantity (EOQ) dan Reoder Point (ROP) di Apotek AXY tahun 2017, Jurnal MODUS, ISSN 08521875, Vol. 30 (1): 71-95,2017.

Hendriani, T., Yamin, M., \& Dewi, A.P., Sistem Peramalan Persediaan Obat dengan Metode Weight Moving Average dan Reorder Point (Studi Kasus: Puskesmas Soropia), Semantik, ISSN: 2502-8928, Vol.2, No.2 Juli0Desember, 2016

Pradnyana, G.A., Sunarya, I.G.M.A., \& Diyayana, D.G.H., Pengembangan Aplikasi Pengendalian Persedian Obat di Apotek Menggunakan Metode Hybrid Periodic Order Quantity- Moving Average, Journal of Natural Science and Engineering, Vol.1 (3), 2017.

Riyadi, S., Aplikasi Peramalan Penjualan Obat Menggunakan Metode Pemulusan (Studi Kasus: Instalasi Farmasi RSUD dr. Nurjabi), Seminar Nasional Teknologi
Informasi dan Multimedia 2015, ISSN : 2302-2805, 2015.

Tresnani, HW, Sihabuddin, A, Mustofa, K., Optimasi Parameter Pada Metode Peramalan Grey Holt-Winter Exponential Smoothing dengan Golden Seection, Jurnal Informatika Dapertemen Ilmu Komputer dan Elektronika, FMIPA UGM, Yogyakarta 2018. 